\title{
Kajian Potensi Kayu Manis dan Teh sebagai Pangan Antidiabetes
}

\author{
Nawasari Indah Putri S. \\ Jurusan Gizi, Politeknik Kesehatan Tanjungkarang, Indonesia \\ Email: nawasariindah@gmail.com
}

\begin{abstract}
Cinnamon and Tea as an Antidiabetic Food. Diabetes mellitus is a metabolic disease characterized by hyperglycemia due to defects in insulin secretion, insulin action, or both. Type 2 Diabetes Mellitus (T2DM) can be controlled by healthy food and adequate physical activities. Some foods can be used for diabetes control such as cinnamon and tea. This paper determined to study cinnamon and tea researches as an antidiabetic food. All researches about cinnamon and tea as an antidiabetic were collected. It was found that cinnamon (Cinnamomum burmanii Blume) and tea (Camelia sinensis L) have many health potentials, such as antioxidants, antibacterial, antidiabetic. Cinnamon shows the ability to lower fasting blood glucose, HbAlc, and plasma lipids; altered postprandial glucose patterns, increased antioxidants and decreased plasma inflammatory markers. In the other hand, tea as the second most consumed drinks in the world could preventing or controlling diabetes with decrease digestive enzyme and intestinal GLUT activity, decrease gluconeogenesis gene expression, increase insulin sensitivity, and protect beta pancreatic. Tea can prevent the risk of T2DM disease if consumed as much as 3 cups per day. It was concluded that both foods can be used to control type 2 diabetes mellitus if consumed in an adequate amount.
\end{abstract}

Keywords: Antioxidant, Cinnamon, Tea, Type 2 Diabetes Mellitus

\begin{abstract}
Abstrak: Kajian Potensi Kayu Manis dan Teh sebagai Pangan Antidiabetes. Diabetes melitus merupakan penyakit metabolik dengan karakteristik hiperglikemia yang terjadi karena kelainan sekresi insulin, kerja insulin, atau kedua-duanya. Diabetes Melitus Tipe 2 (DMT2) dapat dikontrol melalui pola pangan yang sehat dan aktivitas fisik yang cukup. Pangan yang sudah diteliti dapat digunakan untuk pengendalian penyakit diabetes diantaranya adalah kayu manis dan teh. Makalah ini bertujuan untuk mempelajari penelitian terhadap kayu manis dan teh sebagai pangan antidiabetes. Semua penelitian terkait kayu manis dan teh sebagai pangan antidiabetes dikumpulkan. Hasil Kajian menunjukkan bahwa kayu manis(Cinnamomum burmanii Blume)dan teh (Camelia sinensis L)banyak memiliki potensi kesehatan, diantaranya adalah sebagai antioksidan, antibakteri, dan antidiabetes. Kayu manis memiliki kemampuan untuk menurunkan kadar glukosa, HbAlc, dan lipid plasma; merubah pola glukosa postprandial,meningkatkan antioksidan dan menurunkan senyawa penanda inflamasi plasma. Sementara itu, teh yang merupakan minuman kedua terbanyak dikonsumsi di dunia dapat mencegah atau mengendalikan diabetes dengan cara menurunkan aktivitas enzim pencernaan dan aktivitas GLUT usus, menurunkan ekspresi gen enzim glukoneogenesis, meningkatkan sensitivitas insulin, dan melindungi sel beta pankreas. Teh dapat mencegah resiko terjadinya penyakit DMT2 jika dikonsumsi sebanyak 3 cangkir perhari. Dapat disimpulkan bahwa kedua bahan pangan dapat digunakan sebagai pangan antidiabetes jika dikonsumsi dalam jumlah yang cukup.
\end{abstract}

Kata kunci: Antioksidan, Kayu Manis, Diabetes Melitus Tipe 2, Teh

Diabetes melitus merupakan penyakit metabolik dengan karakteristik hiperglikemia yang terjadi karena kelainan sekresi insulin, kerja insulin, atau kedua-duanya dan terbagi menjadi diabetes tipe 1, tipe 2, maupun gestasional (Perkeni 2011). Penderita penyakit ini terus mengalami peningkatan setiap tahun. Menurut International Diabetes Federation (IDF) penderita diabetes melitusdunia usia 20-79 tahun mencapai 415 juta jiwa atau $8,8 \%$ dari total populasi dimana sebanyak $75 \%$ tinggal di negara berkembang. Dari banyaknya kasus diabetes melitus, $87-97 \%$ masuk ke dalam kategori diabetes mellitus tipe 2 (DMT2). Indonesia sendiri menempati peringkat keenam negara penderita DM tertinggi dengan jumlah sekitar 10,0 juta jiwa (IDF 2017).

Kondisi stres oksidatif dapat menyebabkan DMT2 karena memicu resistensi insulin pada jaringan perifer dan merusak sekresi insulin dari 
sel beta pankreas. Stres oksidatif dapat menyebabkan autooksidasi glukosa, aktivasi jalur metabolisme poliol, jalur heksosamin, pembentukan diasil gliserol, aktivasi protein kinase C, dan pembentukan Advanced glycation endproducts (AGEs) yang selanjutnya dapat memperparah penyakit DMT2 (Lazo-de-la-vegaMonroy dan Fernandez-Mejia 2013). Kondisi hiperglikemia yang berlanjut juga terlibat dalam proses pembentukan radikal bebas. Stres oksidatif dapat dihambat dengan antioksidan karena konsumsi pangan yang memiliki aktivitas antioksidan dapat menekan risiko penyakit degeneratif seperti DMT2 dan mempengaruhi kondisi stres oksidatif penderita DMT2 (Zatalia dan Sanusi 2013).

Gaya hidup yang tidak sehat, kegemukan dan aktivitasfisik yang rendah merupakan faktor risiko penyakit DMT2. Oleh karena itu pengaturan pola makan, aktivitas fisik yang cukup serta penggunaan obat-obatan merupakan anjuran dalam pencegahan dan pengendalian penyakit diabetes terutama dalam pengendalian kadar glukosa dalam darah. Pangan sehat bagi penderita DMT2 harus memenuhi kebutuhan zat gizi serta komponen bioaktif yang dapat menurunkan atau mencegah peningkatan glukosa puasa (Hartoyo et al. 2010).

WHO pada tahun 2008 memberikan rekomendasi pola pangan yang sehat yaitu berupa pangan nabati, utuh, dan alami.Secara umum hampir semua pangan nabati baik untuk pencegahan dan pengendalian diabetes melitus dan penyakit kronis lainnya. Prangdimurtiet al. (2006) menyatakan bahwa pangan nabati yang kaya antioksidan dapat menurunkan kadar MDA hati dan meningkatkan aktivitas katalase hati pada tikus percobaan. Pangan yang sudah ditelitidapat digunakan untuk pengendalian penyakit diabetes diantaranya adalahkayu manis, teh, paria, fenugreek,jinten, bawang bombay, kedelai, kelompok berry dan masih banyak lainnya (Rudkowska 2009; Najm dan Lie 2010; Thondre 2013; Mohammed 2014). Pangan tersebut digunakan sebagai bagian dari diet sehari-hari maupun dalam bentuk suplemen.

Kayu manis (Cinnamomum burmanii Blume) merupakan salah satu dari 250 spesies cinnamomumdan bagian yang dimanfaatkan umumnya berupa kulit batang. Kulit batang kayu manis mengandung karbohidrat 59,55\%; protein 4,65\%; lemak 2,2\%; serat 20,3\%; abu 3,55\% dan air $9,9 \%$. Dibidang industri kayu manis dimanfaatkan sebagai flavoring agent dan pewarna dan dibidang kesehatan dimanfaatkan sebagai obat tradisional karena memiliki sifat antimikroba dan antidiabetes (Thomas dan Kuruvilla 2012).

Teh (Camelia sinensis L) merupakan minuman kedua terbanyak dikonsumsi di dunia dan dipercaya memiliki efek kesehatan yang baik. Klasifikasi teh berdasarkan pengolahannya terbagi menjadi teh hijau yang tidak mengalami proses fermentasi, teh hitam yang mengalami proses fermentasi total dan teh oolong yang mengalami proses fermentasi sebagian. Teh hijau kaya akan polifenol yang disebut dengan katekin dan bobotnya mencapai 30-40\% berat kering teh. Katekin merupakan antioksidan yang kuat dan dapat mencegah kerusakan jaringan dari radikal bebas (Grant dan Dworakowska 2013). Teh dapat dimanfaatkan sebagai obat antidiabetes karena memiliki kemampuan menyerupai acarbose, yaitu memperlambat proses metabolisme karbohidrat menjadi glukosa (Sejati, 2016).

Makalah ini bertujuan untuk mengkaji penggunaan kayu manis dan teh dalam pemanfaatan sebagai pangan antidiabetes baik dalam bentuk suplemen maupun sebagai bagian diet sehari-hari. Dengan terbitnya makalah ini, diharapkan masyarakat pada umumnya dan penderita DMT2 pada khususnya mendapatkan informasi bahwa kayu manis dan teh dapat dimanfaatkan sebagai pangan alternatif dalam pencegahan dan pengendalian penyakit DMT2.

\section{KAJIAN PUSTAKA}

Metode yang diambil dalam penulisan artikel ilmiah tentang Kajian Potensi Kayu Manis dan Teh sebagai Pangan Antidiabetes ini adalah dengan mengumpulkan pustaka-pustaka hasil penelitian baik dalam bentuk artikel ilmiah pada jurnal, pada karya tulis, maupun buku terbitan yang menggambarkan kayu manis dan teh sebagai pangan antidiabetes. Hasil penelitian lain tentang kayu manis dan teh yang tidak terkait dengan pemanfaatan kedua pangan tersebut dalam pencegahan dan pengendalian penyakit diabetes tidak akan dipakai sebagai sumber pustaka.

\section{Potensi Kesehatan Kayu Manis dan Teh}

Potensi kesehatan yang dimiliki kayu manis cukup banyak karena kayu manis dapat bertindak sebagai antioksidan, antiinflamasi, antibakteri, dan antidiabetes. Penelitian tentang efek kayu manis terhadap kesehatan umumnya difokuskan pada potensinya sebagai pencegah insulin resistan, sindrom metabolik, dan DMT2. Penggunaan kayu manis dalam penanganan 
penyakit diabetes melitus sudah banyak dilakukan baik secara in vitro maupun in vivo.

Penelitian awal secara in vitro pada sel lemak epididimis tikus menunjukkan bahwa komponen larut air kayu manis dapat meningkatkan aktivitas insulin. Akan tetapi, kayu manis juga dilaporkan banyak mengandung senyawa seperti sinamaldehid, camphene, eugenol, $\gamma$-terpinen, dan polifenol lainnya; mengandung mineral sepertikalsium, kromium, tembaga, besi, yodium, mangan, fosfor, kalium, seng; dan vitamin sehingga belum diketahui secara jelas senyawa yang meningkatkan aktivitas insulin tersebut (Rafehi et al., 2012).

Pengujian lain secara in vitro menunjukkan bahwa ekstrak larut air kayu manis yang mengandung senyawa polimer polifenol memiliki kemampuan meningkatkan aktivitas insulin sebanyak 20kali dibandingkan ekstrak tanaman lainnya, sedangkan senyawa larut lemak dari kayu manis tidak menunjukkan aktivitas serupa.Senyawa polifenol kayu manis yang meningkatkan aktivitas insulin digolongkan ke dalam polifenol tipe A seperti yang terlihat pada Gambar 1 dimana senyawa terbanyak yang ditemukan umumnya berupa senyawa polifenol trimer dengan berat molekul $864 \mathrm{Da}$ dan tetramer dengan berat molekul 1152 Da (Anderson et al., 2004).

Penelitian secara in vivo menunjukkan bahwa kayu manis meningkatkan penyerapan glukosa pada tikus perlakuan (Qin et al. 2003). Selain itu, ekstrak kayu manis juga mampu menstimulasi keberadaan insulin reseptor (IR) $\beta$ dan meningkatkan fosforilasi tirosin IR substrate1 (IRS1) dan IRS1/phosphoinositide 3-kinase (PI3K) pada otot rangka tikus.

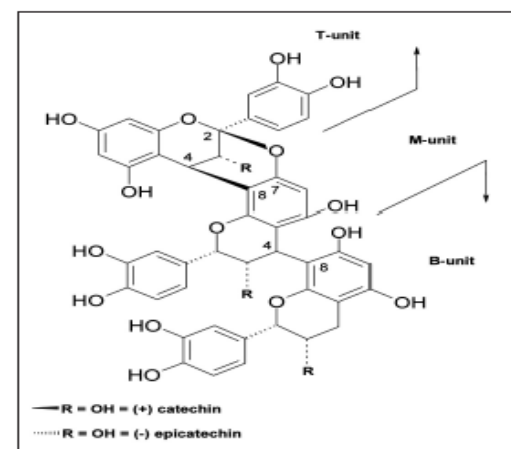

\section{Gambar 1. Struktur Polifenol Tipe A padaEkstrak Larut Air Kayu Manis (Anderson et al. 2004)}

Kayu manis yang digunakan sebagai pangan antidiabetes umumnya berupa serbuk maupun ekstrak larut air dari kayu manis. Namun pemanfaatan kayu manis sebagai antidiabetes tidak hanya dari kulit batangnya saja tetapi juga dari minyak atsiri yang dihasilkan. Penelitian in vivoPinget al. (2010) menyatakan bahwa glukosa puasa tikus yang diberi pakan minyak kayu manis pada konsentrasi $100 \mathrm{mg} / \mathrm{kg}$ menurun secara nyata selama 35 hari. Selain itu, terjadi penurunan pada nilai C-peptida, trigliserida, kolesterol total, dan nitrogen urea serum darah tikus.Toleransi glukosa pada tikus perlakuanjuga lebih baik daripada tikus kontrol dan sel beta pankreas mengalami peningkatan reaksi imunitas.

Teh memiliki 4 senyawa katekin yang yaitu epikatekin (EC), epikatekin galat (ECG), epigalokatekin (EGC) dan epigalokatekin galat (EGCG) (Grant dan Dworakowska 2013). Keempat struktur polifenol teh dapat dilihat pada Gambar 2. Jenis teh yang paling banyak mengandung katekin adalah teh hijau. Teh hitam dan teh oolong karena mengalami proses pengolahan berupa fermentasi, lebih banyak mengandung teaflavin dan tearubigin. Senyawa katekin yang yang paling banyak ditemui adalah EGCG.

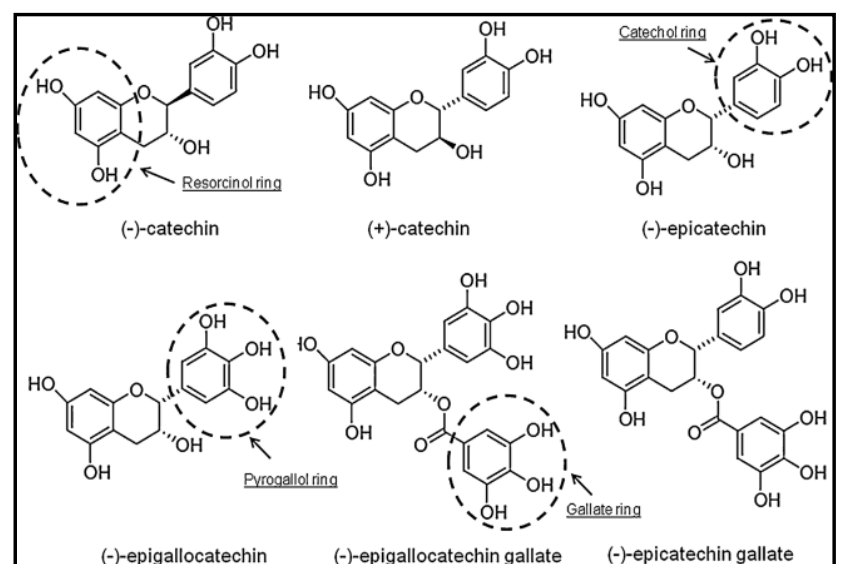

Gambar 2. Senyawa Polifenol yang Terdapat pada Teh hijau (Parket al. 2014)

EGCG dapat bekerja menyerupai insulin sehingga berpengaruh terhadap glukoneogenesis (pembentukan glukosa dari senyawa nonkarbohidrat) yaitu dengan cara menghambat ekspresi gen phosphoenolpyruvate carboxykinase (PEPCK) dan glucose-6-phosphate. Selain itu, EGCG juga membantu proses fosforilasi protein yang terkait dengan insulin dan meningkatkan aktivitas insulin (Waltner-Law et al. 2002). EGCG juga meningkatkan ekspresi glukokinase mRNA sehingga memperbaiki metabolisme glukosa dan lipid pada sel hepatoma tikus H4IIE dan meningkatkan toleransi glukosa oral pada tikus diabetes (Wolfram et al. 2006). Mekanismenya melalui aktivasi IRS2 dan AMPactivated protein kinase (AMPK) pada sel betapankreas oleh EGCG (Cai dan Lin 2009).

Penelitian lain menggunakan sel HepG2 manusia yang diberi perlakuan glukosa tinggi 
menunjukkan hasil bahwa EGCG membantu menurunkan sinyal yang distimulasi oleh insulin melalui penurunan fosforilasi IRS1. Kondisi tinggiglukosa akan meningkatkan fosforilasi IRS1 yang menyebabkan penurunan fosforilasi insulin-stimulated akt/PKB (protein kinase serin/treonin yang memegang peranan penting dalam proses seluler seperti metabolism glukosa, proliferasi sel, apoptosis, transkripsi, dan migrasi sel) (Lin dan Lin 2008). Hal ini diperkuat oleh Murase et al (2009) yang menyatakan bahwa katekin menginduksi peningkatan aktivitas AMPK- $\alpha$ dan meningkatkan fosforilasi LKB1 yang merupakan tumor suppressor protein dan AMPK-kinase utama. Katekin juga menurunkan kadar 8-OH dG yang merupakan marker stres oksidatif pada DNA dan faktor risiko terjadinya aterosklerosis, kanker, dan diabetes (Wu 2004).

EGCG teh menunda waktu terjadinya DMT1 pada tikus non diabetes (Fu dan Zhen, 2010). Teh juga membantu menunda terjadinya resistensi insulin pada tikus yang mengalami DMT2. Teh menurunkan stres oksidatif yang ditandai dengan adanya penurunan peroksidasi lipid plasma, oksidasi grup sulfurhidril, dan kerusakan DNA (Hininger-Favier et al. 2009). Selain itu konsumsi teh juga meningkatkan sensitivitas insulin dan menurunkan kadar glukosa darah tikus percobaan (Grant dan Dwaroska, 2013).

\section{PEMBAHASAN}

Kayu manis dan teh memiliki potensi sebagai pangan antidiabetes yang dapat dimanfaatkan untuk mencegah atau mengendalikan penyakit diabetes pada penderita diabetes terutama DMT2. Hal ini diperkuat dengan hasil-hasil penelitian tentang kedua bahan pangan tersebut baik pada penelitian yang menggunakan hewan percobaan ataupun manusia sebagai subjek penelitian melalui pengujian klinis.Berikut ini adalah hasil kajian pustaka terhadap penelitian-penelitian yang terkait dengan potensi kayu manis dan teh sebagai pangan antidiabetes.

\section{Mekanisme Molekular Kayu Manis dan Teh sebagai Pangan Antidiabetes}

Mekanisme utama kayu manis sebagai antidiabetes fokus pada kemampuan ekstrak larut air kayu manis yang membantu proses insulin signalling. Kayu manisdapat meningkatkan autofosforilasi reseptor insulin dan menurunkan aktivitas tirosin fosfatase (enzim yang menginaktivasi reseptor insulin secara in vitro). Dampak dari kedua hasil diatas adalah meningkatnya sensitivitas insulin (Rafehi et al, 2012) seperti yang terlihat pada Gambar 3.

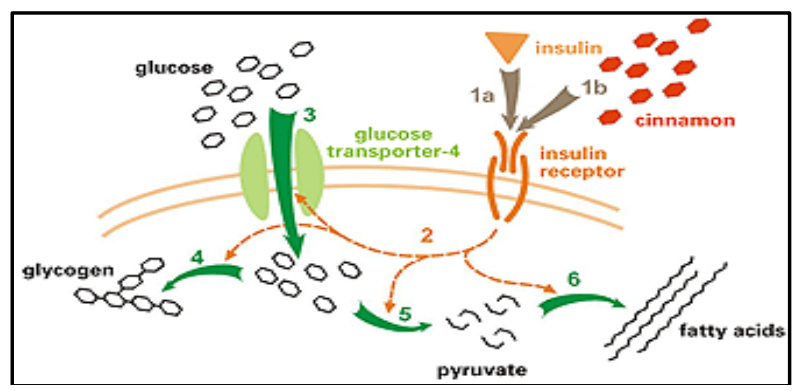

Gambar 3. Peran Kayu Manis dalam Meningkatkan Sensitivitas Insulin (Block, 2009)

Kayu manis juga meningkatkan glucose utilization pada tikus jantan yang diberi pakan tinggi fruktosa. Kayu manis dapat mencegah perkembangan lebih lanjut dari resistensi insulin melalui peningkatan sinyal insulin ataupun melalui jalur nitric oxide (NO) di otot rangka. Ekstrak larut air kayu manis (Cinnulin PF) juga memperbaiki sensitivitas insulin pada manusia (Qin et al, 2010a).

Kayu manis meningkatkan uptake glukosa dan meningkatkan ekspresi glucose transporter 4 (GLUT4: komponen yang memfasilitasi penyerapan glukosa didalam tubuh) pada sel adiposa 3T3-L1.Cinnulin PF juga menurunkan glukosa darah, insulin plasma dancluster of differentiation-36 (CD36) yang merupakan marker resistensi insulin (Handberg 2006). Ekstrak kayu manis juga menghambat retinolbinding protein 4 (RBP4) yang dapat meningkatkan resistensi insulin di plasma dan jaringan adiposa. Ekstrak kayu manis juga mengatur ekspresi gen yang terkait glukosa seperti meningkatkan ekspresi GLUT1, GLUT4, mengaktivasi glycogen syntehsis 1, dan menghambatglycogen synthase kinase $3 \beta$ mRNA (Qinet al. 2010b), juga terjadi peningkatan biosintesis glikogen (Rafehi et al., 2012).

Mekanisme kayu manis lainnya adalah dalam aktivasi faktor transkripsi yaitu peroxisome proliferator-activated receptor (PPARs). PPARs merupakan senyawa yang terlibat dalam resistensi insulin dan adipogenesis dimana salah satu pengobatan dalam penanganan penyakit DMT2 adalah pemberian obat seperti thiazolinedionesyang merupakan PPARsagonist. Ekstrak larut air kayu manis dapat meningkatkan ekspresi PPAR $\gamma$ dan PPAR $\alpha$ baik secara in vitro maupun in vivo pada sel adiposa tikus. Pada 3T3L1 menunjukan peningkatan ekspresi PPAR $\gamma$ dan PPARa juga meningkatkan ekspresi gen 
target seperti GLUT4, CD36,lippoprotein lipase (LPL), fatty acid synthase (FAS), dan acyl CoA oxidase (ACO). Proses ini dapat dilihat pada Gambar 4.

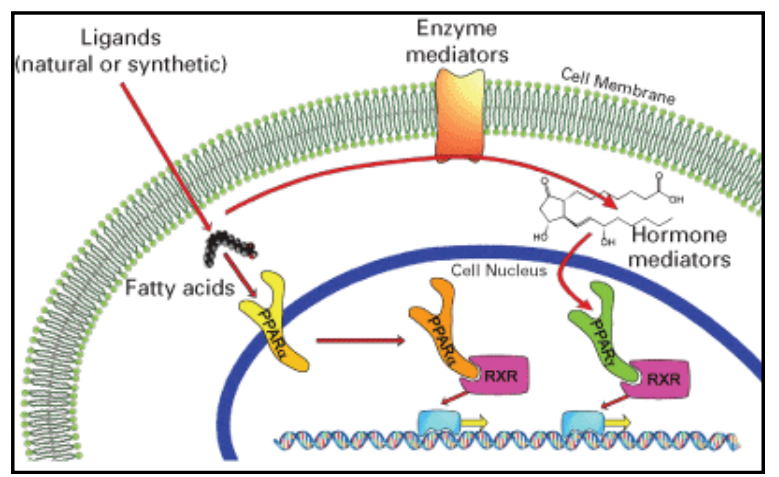

Gambar 4. Ligan (Sintetis/Alami seperti Kayu Manis) Menginisiasi Proses dalam Sel yang Mengatur Ekspresi Gen. Reseptor X Retinoid (RXR) Berikatan dengan PPARa dan PPAR $\gamma$ dan Mempengaruhi Ekspresi Gen (Block, 2009)

Secara in vivo pada tikus model yang mengalami diabetes menunjukkan hasil bahwa tikus yang diberi tambahan ekstrak kayu manis pada pakannya memiliki toleransi glukosa intraperitoneal yang lebih baik dari tikus kontrol. Selain itu, ekstrak kayu manis juga mampu menurunkan jumlah asam lemak bebas serum dan hiperinsulinemia (Rafehi et al. 2012).

Kayu manis juga mampu menghambat atau meredam terjadinya inflamasi pada penderita DMT2. Hal ini terlihat dari meningkatnya ekspresi gen tristetraprolin mRNA pada sel adipose 3T3-L1. Tristetraprolin merupakan protein anti inflamasi dan umumnya akan mengalami penurunan ekspresi gen pada penderita sindrom metabolik yang mengalami obesitas (Cao et al. 2007). Selain itu, kayu manis juga menghambat ekspresi interleukin-1 $\beta$ (IL$1 \beta$ ), IL-6, Tumor Necrosis Factor- $\alpha$ (TNF- $\alpha$ ) dan siklooksigenase-2 (COX-2) yang merupakan agen proinflamasi dan proliferasi (Cao et al. 2008; Junli et al. 2012). Konsumsi Cinnulin PF secara oral pada tikus dan hamster membantu menghambat produksi berlebih dari lipoprotein apoB48 dan trigliserida serum. Selain itu, secara ex vivo ekstrak kayu manis menghambat sekresi berlebih dari apoB48 yang diberi sel enterosit dengan perlakuan TNF- $\alpha$ pada medium. Penghambatan lipoprotein apoB48 diharapkan dapat mencegah penyakit aterogenik pada penderita DMT2.

Ekstrak kayu manis menghambat CD36, microsomal triglyseride transfer protein (MTP), phosphatase dan tensin homolog, dan meningkatkan ekspresi sterol reglucosatory element-binding protein (SREBP)-1c dalam eritrosit dengan perlakuan TNF- $\alpha$. Oleh karena itu ekstrak kayu manis diduga menurunkan inflamasi akibat dislipidemia dan menurunkan faktor resiko yang berhubungan dengan penyakit kardiovaskuler. Selain itu, ekstrak kayu manis juga berperan dalam mengontrol metabolisme lipid (Qin et al. 2010a). Hasil penelitian Sejati et al.(2016) juga menyebutkan bahwa ekstrak larut air kayu manis (Cinnulin PF) mampu menghambat pembentukan IL-6 dan COX-2 yang merupakan faktor penanda inflamasi.

Kayu manis memiliki komponen fenolik yang tidak hanya bertindak sebagai senyawa antioksidan tetapi juga membantu menghambat pembentukan produk akhir proses glikasi yang terkait dengan kemampuannya memerangkap senyawa reactive oxygen species (ROS) dan menangkap reactive carbonyl species (Peng et al. 2008).Polifenol kayu manis juga meningkatkan aktivitas SOD (Super Oxide Dismutase) dan GSH-px (Glutation peroxidase) dan menurunkan MDA (malondialdehid) pada tikus diabetes (Li et al. 2013). Ekstrak kayu manisterutama senyawa prosianidin tipe A trimer maupun tetramer juga menghambat proliferasi sel yang diinduksi oleh vascular endothelial growth factor (VEGFfaktor mitogenik dan angiogenik dalam perkembangan tumor) (Lu et al. 2010). Hasil penelitian lain menunjukkan bahwa ekstrak kayu manis juga dapat memiliki efek kesehatan yang baik terhadap penyakit Alzheimer (Qin et al. 2010a). Secara lengkap, mekanisme kayu manis terhadap penangan penyakit diabetes dapat dilihat pada Gambar 5.

Kemampuan teh sebagai agen antihiperglikemik untuk mengendalikan penyakit diabetes terjadi melalui proses yang kompleks. Pertama, kemampuan teh dalam menurunkan kadar glukosa darah tergantung dari selera makan peminumnya. Kedua, ekstrak teh hijau atau EGCG menurunkan penyerapan karbohidrat dari usus dengan cara menghambat aktivitas $\alpha$ amilase, sakrase, atau $\alpha$-glukosidase usus. Ketiga, teh hijau memperbaiki penurunan massa pankreas yang diinduksi oleh bebagai dosis rendah streptozotoxin (STZ) pada tikus. Keempat, polifenol teh menurunkan stres oksidatif pada tikus melalui penurunan nilai alkaline phosphatase (ALP), glutamic piruvic transaminase (GPT), dan lipid peroxidase (LPO) hati dan menurunkan blood urea nitrogen (BUN) dan kreatinin ginjal.Kelima, adanya perubahan sistem imun dimana ada peningkatan produksi immunoglobulin (Ig) pada tikus jantan. EGCG, ECG, dan EGC merangsang produksi IgE pada 
konsentrasi $1 \mathrm{mM}$ dan menghambat pada konsentrasi dibawah $10 \mu \mathrm{M}$ dan merangsang produksi IgA dan IgG pada konsentrasi $10 \mu \mathrm{M}$. Keenam, teh meningkatkan sensitivitas insulin dengan cara meningkatkan uptake glukosa oleh sel otot, peningakatan pengikatan insulin ke sel adiposa, dan peningkatan ekspresi GLUT4. Dan yang terakhir, adalah katekin teh mengatur level mRNA untuk enzim glukoneogenesis seperti phosphoenol-pyruvate carboxykinase (PEPCK) dan glucose-6-phosphatase (G6Pase) dalam hati tikus (Kao et al, 2006).

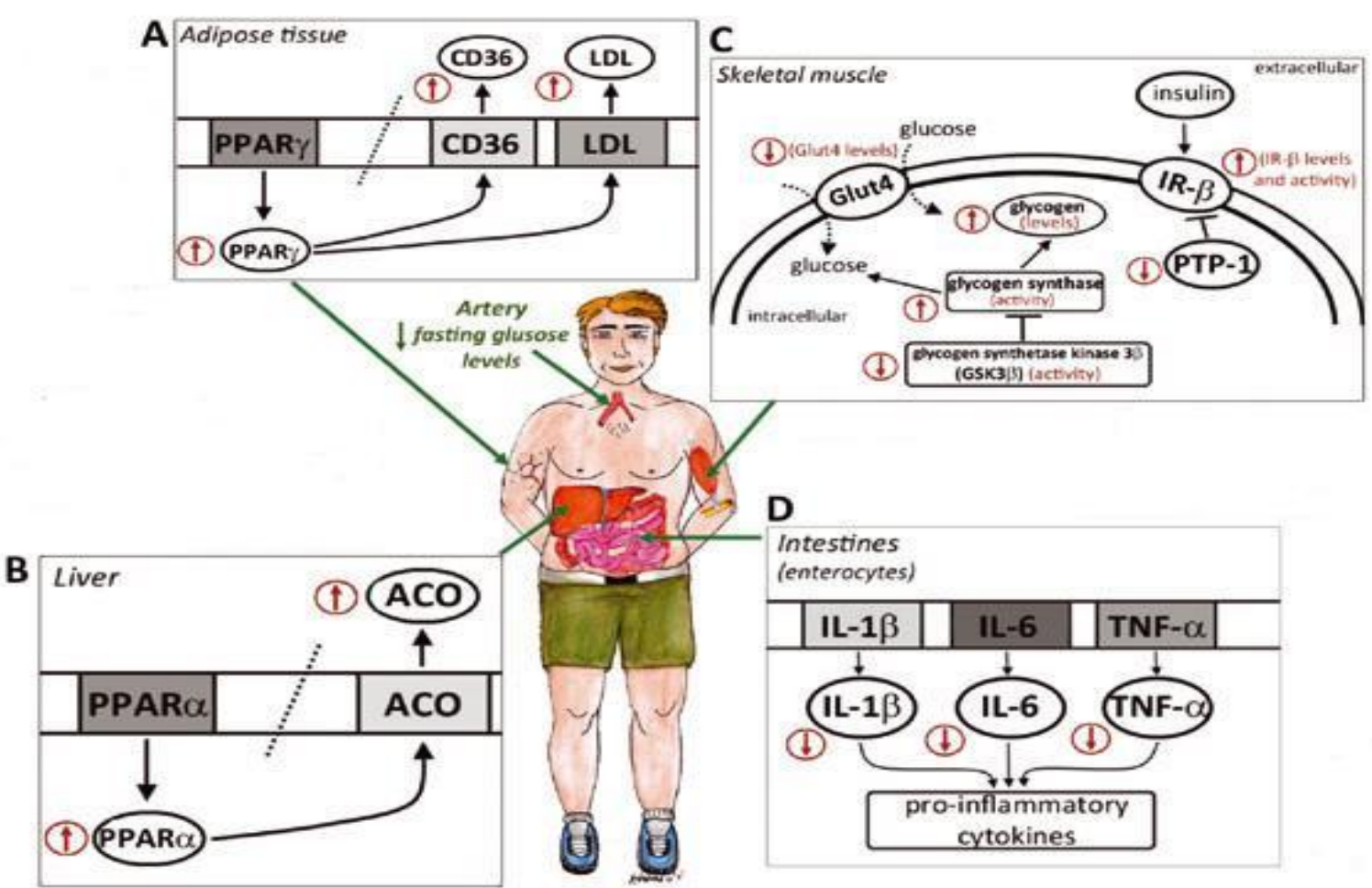

Gambar 5. Mekanisme Kayu Manissebagai Pangan Nutrasetikaldalam Penanganan Penyakit Diabetes (Rafehi et al., 2012)

Mekanisme kerja dari EGCG teh hijau dalam penanganan diabetes seperti yang terlihat pada Gambar 6 dapat melalui beberapa jalur yaitu: (1) menurunkan aktivitas enzim pencernaan, (2) menurunkan aktivitas GLUT usus terutama sodium-dependent glucose transporter1 (SGLT1), (3) menurunkan ekspresi gen enzim glukoneogenesis, (4) meningkatkan sensitivitas insulin, (5) meningkatkan aktivitas insulin mimetic, (6) merubah status reaksi redoks, (7) meningkatkan pertahanan pada hati, sel beta pankreas, dan sel lainnya, dan (8) menurunkan massa adipose, resistin dan lemak darah (Kao et al.2006).

Park et al (2014) menyatakan bahwa mekanisme molekuler senyawa katekin dalam penanganan DMT2 tergantung dari konsentrasi, jenis, dan struktur katekin. Katekin dapat menghambat SGLT1 dan GLUT dengan konsentrasi yang sangat rendah yaitu kurang dari $1 \mu \mathrm{M}$ sedangkan untuk menghambat penyerapan alcohol dibutuhkan konsentrasi lebih dari 100 $\mu \mathrm{M}$. EGCG teh juga menghambat sensitivitas PIP dan ATP serta menghambat saluran $\mathrm{K}_{\mathrm{ATP}}$ secara langsung dengan konsentrasi kurang dari 10 $\mu \mathrm{M}$.Semua jenis katekin mampu meningkatkan sekresi RBP4 dan menangkap radikal bebas. Selain itu, katekin juga menurunkan ekspresi gen PPAR $\gamma$ dan adiponektin. Struktur katekin yang paling banyak berperan adalah struktur cincin galat dan pirogalol seperti pada EGCG dan ECG. Cincin pirogalol bahkan dapat berperan sebagai antijamur. 


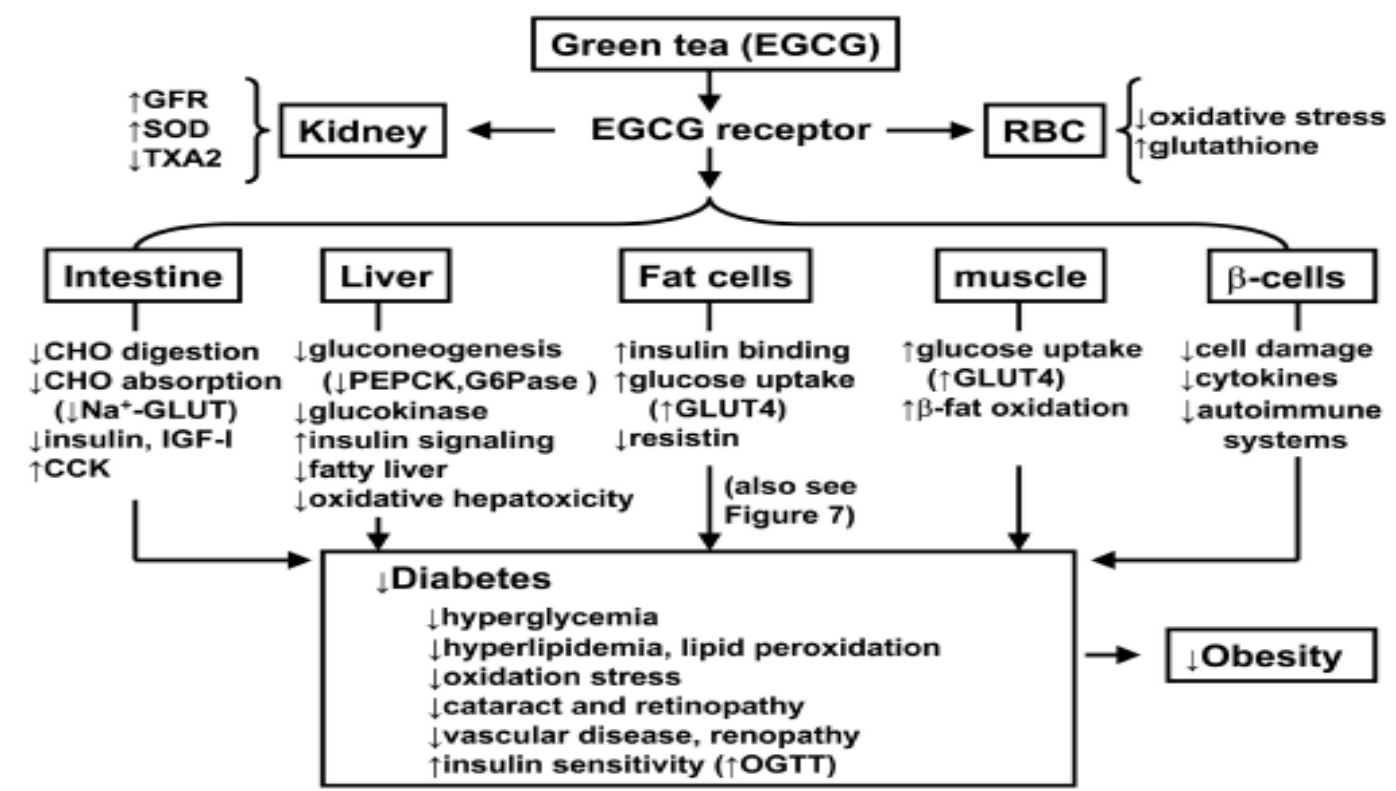

Gambar 6. Mekanisme Kerja EGCG Teh Hijau pada Pengendalian Diabetes (Kao et al., 2006)

Peran Kayu Manis dan Teh sebagai Pangan Antidiabetes pada Manusia

Kayu manis memiliki kemampuan untuk menurunkan kadar glukosa dan lipid plasma manusia. Kayu manisjuga dinyatakan sebagai komponen GRAS (Generally Recognized As Safe) oleh Food Drug Admission (FDA) Amerika. Khan et al (2003) melakukan pengujian klinis pertama tentang kayu manisdengan hasil glukosa darah puasa penderita DMT2 yang diberi ekstrak kayu manis selama 40 hari mengalami penurunan. Profil lipid yang diukur juga menjadi lebih baik dimana kolesterol, trigliserida (TG) dan low density lippoprotein (LDL) mengalami penurunan sedangkan high density lippoprotein (HDL) mengalami peningkatan.

Kayu manis memiliki efek positif dalam penanganan penyakit diabetes melitus terutama DMT2. Kayu manis terbukti efektif menurunkan glukosa darah puasa dan $\mathrm{HbA1c}$, memperbaiki profil lipid serta menurunkan tekanan darah penderita DMT2 (Mang et al, 2006, dan Ziegenfuss et al, 2006). Kayu manis juga meningkatkan sensitivitas insulin dan status antioksidan (Solomon dan Blanin 2007, dan Wang et al, 2007). Pola glukosa post prandial (PP) mengalami penurunan dan memiliki rasa kenyang yang cukup lama karena kayu manismemperlambat waktu pengosongan lambung (Hlebowizc et al., 2007)

Kayu manis menurunkan resiko hiperglikemik dan inflamasi dengan cara menurunkan glukosa PP dan trigliserida, menurunkan aktivitas glikosidase, menahan penyerapan glukosa dan meningkatkan sintesis glikogen (Kirkham et al., 2009). Senyawa larut air kayu manis (cinnulin) berhasil menurunkan kadar glukosa darah puasa sebesar $8,4 \%$ pada penderita pre diabetes dengan pemberian $500 \mathrm{mg}$ cinnulin (setara $10 \mathrm{~g}$ bubuk kayu manis) selama 12 minggu (Ziegenfuss et al., 2006).

Pada wanita yang mengalami polycystic ovary syndrome (PCOS: gangguan hormon pada sistem reproduksi wanita usia subur) menunjukkan adanya peningkatan sensitivitas insulin melalui tes toleransi glukosa oral selama 2 jam. Hasil intervensi dengan pemberian kapsul yang mengandung 333mg ekstrak kayu manis selama 8 minggu pada responden yang sama menunjukkan adanya penurunan resistansi insulin secara nyata (Wang et al, 2007). Terdapat perubahan pola glukosa PP pada orang normal dan obesitas yang mengonsumsi kayu manis sebanyak 6 gram dibandingkan yang tidak. Glukosa darah orang yang mengonsumsi kayu manis mengalami kenaikan yang lebih lambat dengan nilai yang lebih rendah dibanding yang tidak mengonsumsi (Magistrelli dan Chezem, 2012).

Crawford (2009) melakukan pengujian klinis dengan pemberian 1 gram kayu manis bubuk setiap hari selama 90 hari kepada 109 penderita DMT2 yang sudah menjalani pengobatan berupa suntik insulin memberikan hasil bahwa kayu manis efektif dalam menurunkan kadar HbA1c. Hasil yang sama diperoleh oleh Akilen et al., (2010) dimana kayu manis bubuk diberikan kepada 58 penderita DMT2 selama 12 minggu sebanyak 2 gram per 
hari dalam bentuk kapsul. Selain kayu manis bubuk, ekstrak larut air kayu manis juga efektif dalam menurunkan kadar HbA1c pada 66 orang penderita DMT2 yang mengonsumsi obat Glicazide dengan pemberian sebanyak $360 \mathrm{mg}$ ekstrak kayu manis selama 3 bulan.

Penggunaan teh sebagai minuman fungsional dalam penanganan penyakit DMT2 selama beberapa bulan dinilai masih belum efektif.Seperti yang telah dibahas sebelumnya bahwa katekin teh terutama EGCG mempunyai banyak mekanisme dalam menangani DMT2 tetapi konsentrasi yang dibutuhkan untuk melakukan aksi tersebut menyebabkan pasien harus mengonsumsi teh dalam jumlah yang cukup banyak sehingga dikhawatirkan menimbulkan efek samping. Hasil pengujian pada tikus yang diberi STZ, EGCG memperlihatkan aktivitas sebagai prooksidan dan membahayakan keberadaan sel beta pankreas (Park et al, 2014).

Konsentrasi maksimum EGCG dalam darah diperoleh pada menit ke-90 setelah mengonsumsi teh dan diperkirakan EGCG berada dalam sirkulasi darah selama 3-4 jam. Sehingga bisa dikatakan bahwa pengaruh EGCG dalam sistem pencernaan berlangsung selama 1 jam sedangkan pengaruhnya dalam sirkulasi darah berlangsung selama beberapa jam. Sedangkan mekanisme utama EGCG dalam penanganan DMT2 adalah menurunkan aktivitas GLUT usus jika EGCG lebih lama berada dalam sirkulasi darah maka dapat membatasi kerja GLUT sel. Jika dalam 1 cangkir teh hijau terdapat $100 \mathrm{mg}$ EGCG dari $1 \mathrm{~g}$ ekstrak teh maka konsentrasi EGCG di dalam darah diperkirakan mencapai $100 \mathrm{nM}$. Jumlah ini dapat menghambat kerja berbagai GLUT sel sehingga uptake glukosa selular justru dapat terblokir (Park et al, 2014).

Fukino et al. (2008) menyatakan bahwa pemberian suplemen ektrak teh hijau yang mengandung $544 \mathrm{mg}$ polifenol setiap hari selama 2 bulan pada responden dengan kadar glukosa darah puasa diatas rata-rata $(\geq 6,1 \mathrm{mmol} / \mathrm{L})$ tidak berpengaruh terhadap kadar glukosa darah puasa, tekanan darah sistolik, berat, indeks massa tubuh, dan profil lipid responden tetapi menurunkan secara nyata kadar HbA1c. Sedangkan MacKenzie et al (2007) menyatakan tidak ada perubahan kadarHbA1c pada penderita DMT2 yang diberi suplemen teh selama 3 bulan. Suplemen teh tersebut mengandung $150 \mathrm{mg}$ katekin teh hijau yang setara dengan 7 cangkir teh hijau dan $75 \mathrm{mg}$ teaflavin dari teh hitam yang setara dengan 35 cangkir teh hitam serta $150 \mathrm{mg}$ polifenol lainnya.
Hosoda et al (2003) menyatakan bahwa konsumsi teh oolong selama 30 hari (15 gram teh dalam 1,5 liter air) dapat menurunkan kadar glukosa dan fruktosamin plasma penderita DMT2. Namun Ryu et al. (2005) menemukan bahwa konsumsi teh belum dapat menurunkan kadar glukosa darah puasa penderita DMT2 yang meminum the hijau selama 4 minggu. Sejati (2016) menyatakan bahwa teh dapat menghambat aktivitas enzim $\alpha$-glukosidase (enzim pencernaan karbohidrat) hingga $95,95 \%$. Sehingga bisa dikatakan bahwa teh dapat membantu mengatasi kadar glukosa darah penderita DMT2 dengan cara memperlambat proses pencernaan karbohidrat sehingga glukosa yang tersedia di dalam darah dapat diperlambat.

Hasil meta analisis terhadap studi kohort menyatakan bahwa teh dapat menurunkan resiko DMT2 sebesar $20 \%$ jika dikonsumsi 4 cangkir atau lebih dalam sehari (Jing et al, 2009). Studi kohort lainnya menyatakan bahwa konsumsi 3 cangkir teh atau kopi sehari dapat menurunkan resiko DMT2 sebesar 42\% (Dieren et al, 2009). Sedangkan Oba et al (2009) melakukan studi kohort pada penduduk Jepang baik laki-laki maupun perempuan dengan hasil bahwa konsumsi teh hijau tidak berkaitan dengan penurunan resiko diabetes melitus.Bahkan pada wanita, konsumsi teh oolong justru meningkatkan resiko terjadinya DMT2. Hasil lainnya menyatakan bahwa konsumsi teh 3 cangkir sehari menurunkan resiko terjadinya DMT2 namun secara statistik penurunan tersebut tidak berbeda nyata (Yang et al. 2014).

\section{SIMPULAN}

Kayu manis dan teh merupakan pangan yang dapat digunakan dalam penanganan penyakit diabetes melitus tipe 2 . Secara in vitro maupun in vivo, keduanya menunjukkan hasil yang cukup baik. Kedua pangan tersebut dapat bertindak sebagai antioksidan, anti proliferasi, maupun anti inflamasi. Selain itu juga dapat bertindak sebagai insulin mimetic yang dapat meningkatkan uptake glukosa ke sel. Sensitivitas insulin dan toleransi glukosa juga mengalami peningakatan. Para peneliti menemukan penggunaan kedua bahan pangan pada manusia menunjukkan hasil yang bervariasi tetapi pada umumnya terjadi penurunan glukosa darah puasa dan kadarHbA1c pada responden diabetes melitus tipe 2. Resiko penyakit DMT2 dapat dikurangi dengan konsumsi minuman fungsional teh sebanyak 3 cangkir sehari. 


\section{DAFTAR PUSTAKA}

Akilen R, Tsiami A, Devendra D, Robinson N. 2010. Glycated haemoglobin and blood pressure lowering effect of cinnamon in multi-etnic type 2 diabetic patients in the UK: a randomized, placebo controlled, double blind clinical trial. Diabet Med. 27 (10): 1159-1167.

Altschuler JA, Casella SJ, MacKenzie TA, Curtis KM. 2007. The effect of cinnamon on A1C among adolescents with type 1 diabetes. Diabetes Care. 30(4):813-816.

Anderson RA, Broadhurst CL, Polansky MM, Schmidt WF, Khan A, Flanagan VP, Schoene NW, Graves DJ. 2004. Isolation and characterization of polyphenol type-A polymers from cinnamon with insulin-like biological activity. J Agric Food Chem.52 (1) : 65-70.

Blocks W. 2009. The antidiabetes trigger. Life enhancement magazine. New York: Life Enhancement Product Inc

Bryans JA, Judd PA, Ellis PR. 2007. The effect of consuming instant black tea on postprandial plasma glucose and insulin concentrations in healthy humans. $J \mathrm{Am}$ Coll Nutr. 26(5): 471-477.

Cai EP dan Lin JK. 2009. Epigallocatechin gallate ad rutin suppress tea glucotoxicity through activating IRS2 and AMPK signaling in rat pancreatic beta cell. J Agric Food Chem. 57 (20): 9817-9827.

Cao H, Polansky MM, Anderson RA. 2007. Cinnamon extract and polyphenols affect the expression of tristetraprolin, insulin receptor, and glucose transporter 4 in mouse 3T3-L1 adipocytes. J Archives of Biochem and Biophys 459 (2): 214 - 222.

Cao H, Urban Jr JE, Anderson RA. 2008. Cinnamon polyphenol extract affects immune responses by reglukosating antiand proinflammatotry and glucose transporter gene expression in mouse macrophages. J of Nutr. 138(5): 833-840.

Cheng DM, Kuhn P, Poulev A, Rojo LE, Lila MA, dan Raskin L. 2012. In vivo and in vitro antidiabetic effects of aqueous cinnamon extract and cinnamon polyphenol-enhanced food matrix. J. Food Chem. 135 (4): 2994-3002.

Crawford P. 2009. Effectiveness of cinnamon for lowering hemoglobin A1C in patients with type 2 diabetes: a randomized controlled trial. J. Am. Board Fam Med. 22(5): 507512.
Fu Z dan Zhen W. 2010. Epigallocatechin gallate delays the onset of type 1 diabetes in spontaneous non-obese diabetic mice. $\mathrm{Br} \mathrm{J}$ Nutr. 105(8):1218 - 1225

Fukino Y, Ikeda A, Maruyama K, Aoki N, Okubo T, Iso H. 2008. Randomized controlled trial for an effect of green teaextract powder supplementation on glucose abnormalities. Eur J of Clin Nutr. 62(8): 953-960.

Grant P and Dworakowska D. 2013. Tea and diabetes: the laboratory and the real world in Tea in Health and Disease Prevention. New York: Elsevier Inc.

Handberg A, Levin K, Hojlund K, Beck-Nielsen H. 2006. Identification of the oxidized low-density lipoprotein scavenger receptor CD36 in plasma: a novel marker of insulin resistance. Circulation. 114(11):11691176.

Hartoyo A, Sukarno, dan Rohmawati E. 2010. Pengaruh fraksinasi non protein kacang komak (Lablab purpureus L. Sweet) terhadap kadar glukosa darah dan malonaldehid tikus diabetes. $J$ Tek dan Ind Pangan. 21(1): 40-44.

Hininger-Favier I, Benaraba R, Covers $S$, Anderson RA, dan Roussel AM. 2009. Green tea extract decrease oxidative stress and improve insulin sensitivity in an animal model of insulin resistance, the fructose-fed rats. J Am Coll Nutr. 28(4): 355-361.

Hlebowicz J, Darwiche G, Bjorgell O, Almer LO. 2007. Effect of cinnamon on postprandial blood glucose, gastric emptying and satiety in healthy subjects. Am J Clin Nutr. 85 (6): 1552-1556

Hlebowicz J, Hlebowicz A, Lindstedt S, Bjorgell O, Hoglund P, and Holst JJ. 2009. Effects of 1 and $3 \mathrm{~g}$ cinnamon on gastric emptying, satiety, and postprandial blood glucose, insulin, glucose-dependent insulinotropic polypeptide, glucagon-like peptide 1, and ghrelin concentrations in healthy subjects. Am J Clin Nutr. 89 (3) : 815-821.

Hosoda K, Wang MF, Liao ML, Chuang CK, Iha M, Clevidence B, Yamamoto S. 2003. Antihyperglycemic effect of oolong tea in type 2 diabetes. Diabetes Care. 26 (6): 1714-1718.

International Diabetes Federation [IDF]. 2017. Diabetes Atlas $8^{\text {th }}$ ed. London. UK.

Tersedia di www.diabetesatlas.org/ 
Jing Y, Han G, Hu Y, Bi Y, Li L Zhu D. 2009. Tea consumption and risk of type 2 diabetes: a meta-analysis of cohort studies. J Gen Intern Med. 24(5): 557-562.

Josic J, Olsson AT, Wickeberg J, Lindstedt S, dan Hlebowizc J. 2010. Does green tea affect postprandial glucose, insulin and satiety in healthy subjects: a randomized controlled trial. J Nutr. 30(9): 63.

Junli Lv, Huang H, Yu L, Whent M, Niu Y, Shi $\mathrm{H}$, Wang TTY, uthria D, Charles D, Yu LL. 2012. Phenolic composition and nutraceutical properties of organic and conventional cinnamon and peppermint. $J$ Food Chem. 132 (3): 1442-1450.

Kao YH, Chang HH, Lee MJ, dan Chen CL. 2006. Tea, obesity, and diabetes: Review. $J$ Mol Nutr Food Res. 50(2): 188-220.

Khan A, Safdar M, Ali Khan MM, Khattak KN, and Anderson RA. 2003. Cinnamon improves glucose and lipids of people with type 2 diabetes. Diabetes Care. 26(12): 3215-3218.

Kirkham S, Akilen R, Sharma S, dan Tsiami A. 2012. The potential of cinnamon to reduce blood glucose levels in patienets with type 2 diabetes and insulin resistance. J Diab, Obes and Metab. 11(12): 1100-111.3

Lacaille-Dubois MA, Franck U, and Wagner H. 2001. Search for potential angiotensin converting enzyme (ACE)-inhibitors from plants. J Phytomedicine. 8(1): 47-52.

Lazo-de-la-Vega-Monroy $M$ dan FernándezMejía C. 2013. Oxidative stress in diabetes mellitus and the role of vitamins with antioxidant actions. In:Oxidative Stress and Chronic Degenerative Diseases-ARole for Antioxidants, Dr. Jose Antonio Morales-Gonzalez (Ed.). InTech. DOI: $10.5772 / 51788$.

Li R, Liang T, Xu L, Li Y, Zhang S, Duan X. 2013. Protective effect of cinnamon polyphenols against STZ-diabetic mice fed high sugar, high fat diet and its underlying mechanism. J. Food and Chem Toxic.51(1): 419-425.

Lin CL dan Lin JK. 2008. Epigallocatechin gallate (EGCG) attenuates high glucoseinduced insulin signaling blockade in human HepG2 hepatoma cells. Mol Nutr Food Res. 52(8): 930-939.

Lu J, Zhang K, Nam S, Anderson RA, Jove R, Wen W. 2010. Novel angiogenesis inhibitory activity in cinnamon extract blocks VEGFR2 kinase and downstream signaling. Carcinogenesis. 31(3):481-488.
Lu T, Sheng H, Wu J, Cheng Y, Zhu J, Chen Y. 2012. Cinnamon extract improves fasting blood glucose and glycosylated hemoglobin level in Chinese patients with type 2 diabetes. J Nutres. 32(6): 408-412.

MacKenzie T, Leary L, dan Brooks WB. 2006. The effect of an extract of green and black tea on glucose control in adults with type 2 diabetes melitus: double blind randomized study. J Metab Clin and Exp. 56(10): 1340-1344.

Magistrelli A dan Chezem JC. 2012. Effect of ground cinnamon on postprandial blood glucose concentration in normal weight and obese adults. J AcNutr and Diet. 112(11): 1806-1809.

Mang B, Wolters M, Schmitt B, Kelb K, Lichtinghagen R, Stichtenoth DO, Hahn A. 2006. Effects of a cinnamon extract on plasma glucose, $\mathrm{HbA1c}$, and serum lipids in diabetes melitus type 2. Eur J of Clin Invest. 36(5): 340-344.

Mohamed S. 2014. Functional foods against metabolic syndrome (obesity, diabetes, hypertension and dyslipidemia) and cardiovascular disease. J Trends in Food Sci \& Tech. 35(2): 114-128

Murase T, Misawa K, Haramizuki S, Dan Hase T. 2009. Catechin-induced activation of the LKB1/AMP-activated protein kinase pathway.Biochem Parmacol. 78(1): 78-84.

Najm W and Lie D. 2010. Herbal use for diabetes, obesity, and metablic syndrome. J Prim Care Clin Off Pract. 37(2): 237254.

Oba S, Nagata C, Nakamura K, Fujii K, Kawachi T, Takatsuka N, Shimizu H. 2010. Consumption of coffee, green tea, oolong tea, black tea, chocolate snacks and the caffeine content in relation to risk of diabetes in Japanese men and women. $\mathrm{Br} J$ Nutr. 103(3): 453-459.

Park JH, Bae JH, Im SS, and Song DK. 2014. Green tea and type 2 diabetes: A review. $J$ Integrative Med Res. 3(1): 4-10.

Peng X, Cheng KW, Ma J, Chen B, Ho CT, Lo C, Chen F, Wang M. 2008. Cinnamon bark proanthocyanidins as reactive carbonyl scavengers to prevent the formation of advanced glycation endproducts. J Agric Food Chem. 56(6):1907-1911.

Perkumpulan Endokrinologi Indonesia [PERKENI]. 2011. Konsensus pengelolaan dan pencegahan diabetes melitus tipe 2 di Indonesia.

Ping H, Zhang G, dan Ren G. 2010. Antidiabetic effects of cinnamon oil in diabetic KK-A ${ }^{y}$ 
mice. J Food and ChemToxico. 48(8-9): 2344-2349.

Prangdimurti E, Muchtadi D, Astawan M, Zakaria FR. 2006. Aktivitas antioksidan ekstrak daun suji (Pleomele angustifolia N.E. Brown). J. Teknol dan Industri Pangan, 17(2): 79-86.

Qin B, Nagasaki M, Ren M, Bajotto G, Oshida Y, Sato Y. 2003. Cinnamon extract (traditional herb) potentiates in vivo insulin-reglukosated glucose utilization via enhancing insulin signaling in rats. Diabetes Res Clin Pract. 62(3):139-148.

Qin B, Panickar KS, and Anderson RA. 2010a. Cinnamon: Potential role in the prevention of insulin resistance, metabolic syndrome, and type 2 diabetes. $J$ Diabetes $S c i$ Technol. 4(3): 685-692.

Qin B, Polansky MM, Anderson RA. 2010b. Cinnamon extract reglucosates plasma levels of adipose-derived factors expression of multiple genes related to carbohydrates metabolism and lipogenesis in adipose tissue of fructose-fed rats. Horm Metab Res. 42(3): 187-193.

Rafehi H, Ververis K, dan Karagiannis TC. 2012. Controversies surrounding the clinical potential of cinnamon for the management of diabetes : Review article. Diabetes, Obesity and Metabolism, 14 (6): 493-499.

Roussel AM, Hininger I, Benaraba R, Ziegenfuss TN, Anderson RA. 2009. Antioxidant effects of cinnamon extract in people with impaired fasting glucose that are overweight or obese. J. Am Cloo Nutr. 28(1): 16-21.

Rudkowska I. 2009. Functional food for health: focus on diabetes. J. Maturitas. 62(3): 263-269.

Ryu OH, Lee J, Lee KW, Kim HY, Seo JA, Kim SG, Kim NH, Baik SH, Choi DS, Choi KM. 2005. Effects of green tea consumption on inflamation, insulin resistance and pulse wave velocity in type 2 diabetes patients. $J$ Diabet Res and Clin Pract. 71(3): 356-358.

Sejati NIP, Prangdimurti E, dan Zakaria FR. 2016. Pengaruh minuman diperkaya cinnulin terhadap MDA dan senyawa inflamasi plasma penderita DMT2. Jurnal Teknologi dan Industri Pangan, 27(1): 51 -58 .

Sejati NIP. 2016. Pengaruh Minuman yang Diperkaya Cinnulin terhadap Parameter Diabetik Responden Diabetes Melitus Tipe-2. [Tesis]. Bogor: Ilmu Pangan.
Program: Pascasarjana Institut Pertanian Bogor.

Solomon TP, Blannin AK. 2007. Effects of shortterm cinnamon ingestion on in vivo glucose tolerance. Diabetes Obes Metab. 9(6).

Solomon TP, Blannin AK. 2009. Changes in glucose tolerance and insulin sensitivity following 2 weeks of daily cinnamon ingestion in healthy humans. Eur J Appl Physiol. 105(6):969-976.

Spadiene A, Savickiene N, Ivanauskas L, Jakstas V, Skesters A, Silova A, Rodovicius H. 2014. Antioxidant effects of Camelia sinensis L. extract in patients with type 2 diabetes. $J$ of Food and Drug Anal.22(4): 505-511.

Stoecker BJ, Zhan Z, Luo R, Mu X, Guo X, Liu Y, Guo Q, Kong J, Anderson RA. 2010. Cinnamon extract lowers blood glucose in hyper-glycemic subjects [abstract]. FASEB J. 24(1):1

Suppapitiporn S, Kanpaksi N, Suppapitiporn S. 2006. The effect of Cinnamon cassia powder in type 2 diabetes mellitus. $J$ Med Assoc Thai.89 (3): S200-S205.

Tang M, Larson-Meyer DE, Liebman M. 2008. Effect of cinnamon and turmeric on urinary oxalate excretion, plasma lipids, and plasma glucose in healthy subjects. Am J Clin Nutr. 87(5): 1262-1267.

Thomas J dan Kuruvilla KM. 2012. Cinnamonin Peter KV (ed.) Handboook of Herbs and Spices. Cambridge:Woodhead Inc.

Thondre PS. 2013. Food base ingredients to modulate bloog glucose. $J$ Adv in Food and Nutr Res. 70(1): 181-227.

van Dieren S, Uiterwaal CS, van der Schouw YT, van der A DL, Boer JMA, Spijkerman A, Grobbee DE, Beulens JWJ. 2009. Coffee and tea consumption and risk of type 2 diabetes. Diabetologia 52(12): 2561-2569.

Vanschoonbeek K, Thomassen BJ, Senden JM, Wodzig WK, Van Loon IJ. 2006. Cinnamon supplementation does not improve glycemic control in post menopausal type 2 diebetes patients. $J$. Nutr. 136(4): 977-980.

Waltner-Law ME, Wang XL, Law BK, Hall RK, Nawano M, and Granner DK. 2002. Epigallocatechin gallate, a constituent of green tea, represses hepatic glucose production. J Biol Chem. 277(38): 3493334940.

Wang JG, Anderson RA, Graham $3^{\text {rd }}$ GM, Chu MC, Sauer MV, Lobo RA. 2007. The effect of cinnamon extract on insulin 
resistance parameters in polycystic ovary syndrome: a pilot study. Fertil Steril. 88(1):240-243.

Wolfram S, Raederstorff D, Preller M, Wang Y, Teixeira SR, Riegger C, Weber P. 2006. Epigallocatechin gallate supplementation alleviates diabetes in rodents. $J$ Nutr. 136(10): 2512-2518.

Wu LL, Chiou CC, Chang PY, Wu JT. 2004. Urinary 8-OHdG: a marker of oxidative stress to DNA and a risk factor for cancer, atehrosclerosis and diabetics. Clin. Chim. Acta. 339(1-2): 1-9.

Yang J, Mao QX, Xu HX, Ma X, Zheng CY. 2014. Tea consumption and risk of type 2 diabetes melitus: a systematic review and meta-analysis update. BMJ open. 4: 1-12.

Zatalia SR dan Sanusi H. 2013. The role of antioxidants in the pathophysiology, complications, and management of diabetes mellitus. Acta Medica Indonesiana, 45(2): 141-147.

Ziegenfuss TN, Hofheins JE, Mendel RW, Landis J, and Anderson RA. 2006. Effect of water soluble cinnamon extract on body composition and features of teh metabolic syndrome in prediabetic men and women. J Intl Society of Sports Nutr. 3(2): 45-53. 